\title{
ECOLOGICAL CONSCIOUSNESS POETRY: A STUDY OF GARY SYNDER'S POETRY ${ }^{i}$
}

\author{
Zaid Najah Merzah ${ }^{1 i i}$ \\ Alaa Ahmed Idrees ${ }^{2}$ \\ ${ }^{1}$ Assistant Lecturer, \\ Imam Ja'afar Alsadiq University in Najaf, \\ Iraq \\ ${ }^{2}$ English Teacher, \\ Faculty of Languages, Kufa University, \\ Iraq
}

\section{Abstract:}

Ecological consciousness poetry is considered as a modern literary movement, it has its roots in the west side of the world originated in the United States of America on the second half of $20^{\text {th }}$ century. The concept of nature was the major theme in the Romantic era. On the other hand, ecowriters have their consideration of nature. This research highlighting on one of the most important parts in this movement which is "ecopoetry" by explaining its implications of nature in Gary Snyder's poetry, who is one of the pioneers of beat generation. The first section of the research concerns with Gary Snyder's early life and highlights on his most significant perspectives. The second one is a kind of a critical part, which concerns with eco-critical approach, its roots, concept, and a list of a critical questions which asks by its critics. The third section is the most important one in my opinion, which is the implication of ecological consciousness poetry in Gary Snyder's poems and how he reads this kind of poetry. And last but not least, a conclusion which sums up my perspectives and readings to the ecocriticism in general, and Gary Snyder's poetry in special.

Keywords: ecological consciousness, American modern poetry, Gary Snyder, modernism

\section{Introduction}

"It's true, a great fuzzy windstorm Like yeast up there today, still The only faint source of hope Is the snow on Kurakake mountain" (Snyder, 2007)

\footnotetext{
${ }^{i}$ The present research work represents an updated version of a previously published article: Merzah, Z. (2021). ECOLOGICAL CONSCIOUSNESS POETRY: A STUDY OF GARY SYNDER'S POETRY. European Journal of Literature, Language and Linguistics Studies, 5(1). doi: http://dx.doi.org/10.46827/ejll1.v5i1.264

ii Correspondence: email zaid.najah@sadiq.edu.iq, alla.ahmedi98@gmail.com
} 
In above-mentioned lines, the poet describes the beauty of the snow's view on the saddle mountain, and how sorrowful when this spectacular scene will disappear and perish.

Although many would argue that nature writing was an important part in Romanticism as a trend, constituting a crucial chunk in their poetry. In the Romantic era, the thematic issue of nature played the major role in literature, and the literary writers deal with nature as their main dish to write about. Their interest was especially in the purity of the nature, and an appreciation for natural beauty. They also concerned with human imagination, and the harmony between nature and man. For William Blake, as an example on the Romantic poets, nature in his writing acted as a gentle guide to the man, Blake believed that humans and nature are united.

Post-modernism on the other hand, represented in ecological poetry offers a different perspective towards nature writing. For in history human beings were never in such a critical need of spiritual unity. In the second half of $20^{\text {th }}$ century Eco-poetry renders the world to this unity. It can best be described as an intuitive attempt to harmonize with the world, a "conversation with God", enacted through nature. It is represented in many forms, such as poetry and literature, painting and sculpture, philosophy and music, and by many other techniques of spirituality (Postnikov, 2001:1).

Eco-poetry writers and poets headlined the ecological issues through their writings in a completely different style than the Romantics. By using new poetic images and symbols to highlight their ideas, they created a new literary movement called later Ecocriticism or Beat Generation. One of the pioneers in the Eco-poetry is the American poet and the essayist Gary Snyder.

Snyder was born in (May 8, 1930) San Francisco, California, US. His family involved in IWW, for this reason he influenced by politically, conscious environment that he grown up with (Martin, 1990: 148).

In his youth, Snyder influenced by D. T. Suzuki's writings, which in fact had been a factor in his decision to study Asian culture and language in University of California Berkeley. In 1959 Snyder published his first works under title "Riprap \& Cold Mountain" this work was a collection of Han Shan's poems "Cold Mountain" which translated by Snyder himself, also poems of his own. After a few years living and went back between Japan and California, Snyder started his own journey as a great part in the Beat Generation.

\section{Literature Review}

In the West, they're used to the dualistic conception of the world in terms of binary oppositions they define both material objects and ideas (rough / smooth, good / evil). They condemn the true to the ideal, valuing the one at the detriment of the other or redefining the one as the other, with Plato. Buddhism subverts these definitional ventures by challenging the unconscious thought's capacity to grasp or express truth in some other direction than misleadingly. Psyche (Oneness) cannot be understood in the understanding of dualistic terms (absolute/conditional, for example).

Gary Snyder's poems are straight away from abstractions, boldly delineating the material world in a series of concrete images. Snyder's lyrics, however, depend as much on what they 
omit as on what they contain. Honeycombing his poems with syntactic and structural ellipses, and refusing to fully determine his imagery, Snyder seeks to disrupt our complacent relationship with our own experience by shortening our customary ways of dividing and conquering that experience, whose chief is language.

Grammars, use manuals, design handbooks and the like attempt to make vocabulary both formal and rational. When conventionally applicable required elements from linguistic systems are excluded if such constructs be lines, sentences or literary types, they are irrational, and their interpretations are thereby problematized. Yet Snyder's methods tend to complicate the interpretation rather than simply. The aim is using the grammatical, syntactic and semantic spaces that permeate even language, the basis for all structuralisms undertakings to allow an instant awareness of that language is not conceived in theory to produce.

Since language needs to use titles provisionally, Zen Buddhist scriptures apply, by one term or another, to an absolute truth trying to help the Zen student achieves his own direct spiritual experience. Yet these terms do not imply in the usual sense, since the "value" they wish to escape from enclosure in some specific phrase. Thinking of the One as an object of certain entities is simply (and wrongly) to define it as such. So, Snyder avoids explicit references to an Absolute.

By eliding both the lone speaker and the One in many of his speeches Snyder follows Buddhism in tacitly affirming the illusory nature of poems of the self. Subject elision is also followed by a textual substitution of the verbs. Using these two forms of ellipsis allows the poet to present activity not in terms of "I" acting, but simply as action taking place.

However, I want to resist explicitly removing an inverse hierarchy about the one he wants to challenge (nothing nothingness for objective reality, let us say, or Absence for Presence), Snyder fills his poems with vivid natural imagery-world, trees, animals-which, in his creation is deeply sensual yet at the same time generic. This generalization of imagery has two aims: it denies reality of (the proper) individuation without denying (the common) particularity and this means that the poem's expressed reality is neither intimate nor traditionally special.

Not entirely present, Snyder's poems allow rather than include, an infinite amount of actualizations - actualizations that the reader can only generate by failing to be merely the consumer of the text. The poems insist that their reader transcend logical and discursive strategies and involve his imagination, and eventually his intellect, vigorously in completing the literary experience.

In addition to the Buddhist (non)conception of the Void, which constitutes its unstated ontological ground, Snyder's poetry incorporates numerous elements of the poetics and stylistic procedures of the T'ang Dynasty China shih poetry and the Japanese haiku. Snyder combines these assumptions and practices with his own imagination experience, and voice to compose a characteristic elliptical mode, whose purpose is to form not an extension of content, but an expression. 


\section{Analysis}

Ecocriticism is a recent development in the literary sense of appreciation. It only gained momentum in the 1990s when it first evolved in the US, and then in the UK. From the very beginning, ecocriticism was based on the assumption that the human world and the physical environment are closely interlinked and that the one is shaped by the other, and therefore the study of the representation of human-nature relationship in literature is of the utmost importance in understanding the environmental predicament of the world today (Gogoi, 2014).

Ecocritism was defined by many literary writers, but the first one who used "ecocritism" term were the American writers Cheryll Glottfelty and Harold Fromm: "ecocriticism is the study of the relationship between literature and the physical environment" (Glottfelty and Fromm, 1996). This definition is simultaneously specific and wide. It describes "ecocritism" basically as a relationship between the literary texts and the environmental system, which turns the definition to be specific. On the other hand, it's considered as a wide definition, because it does not consist of the details that the reader needs for creating a full recognition to the term, or to the approach itself.

Another definition by William Rueckert: "the application of ecology and ecological concepts to the study of literature, because ecology (as a science, as a discipline, as the basis for human vision) has the greatest relevance to the present and future of the world" (Rueckert, 1996:107). This definition seems to be acceptable, because of its richness in the details that the reader is most need, at the same time it is not wide.

\section{The Concept}

Ecocriticism causes a call to literature link to the environmental problems of our day. In other words, ecocriticism is concerned directly with both nature (natural landscape) and the environment (natural and urban landscape). But the attempt to synthesize natural phenomena with literary criticism raises conceptual issues, because ecology itself is an abstract concept that has emerged in a historical context of the academic training process. (Oppermann, 1999: 1).

Using ecology's ontological argument that everything is connected to everything else, ecocriticism seeks to study what is mentioned in Human Ecology as Human Behavior, "a multiorganismic concept" symbolically. That is, to create "an image or idea of holistic entity and then treat that image as a real entity: the 'environment,' 'human ecology,' Gaia or the organismic Earth, the universe, God". (Bennet, 1996: 356- 357).

However, the study of the Earth's conceptual inscriptions as an immersive mechanism in literary texts cannot be the sole appropriate ground for the review or understanding of the literary representations of nature / human relations. Ecocriticism requires a more holistic and interdisciplinary approach from the literary perspective. The problem is whether a theoretical role can be reached which covers the complexity of environmental issues. Therefore, every research into ecological problems in literary theory needs theoretical and practical precision. (Oppermann, 1999: 1).

First, to reform present perceptions and Approaches in critical theory involve a significant extension of the theoretical systems; and second, if critical emphasis is unique to particular types 
of literature, such as nature poetry or prose, then critical lenses need to be expanded in their study. And last but not least if other forms of writing should be included in the ecocritical examination, and considerable effort should then be put into their study as to how they construct or approach ecological issues. If it all happens It is important to examine interactions between the literary and the physical world, ecocritical theory requires an eco-literary structure of certain sophistication, since any connection between these two is essential phenomena require properties of a structural type. The problem is that of choosing an acceptable theoretical viewpoint that synthesizes the real and the literary phenomena. Ecocriticism today is still in the midst of inventing and forming itself, mainly borrowing from other sciences and nature. (Oppermann, 1999:1-2).

\section{A Critical Overview}

Eco-criticism asks the following questions: How nature gets textualized in literary texts to create an eco- literary discourse that would help produce an intertextual as well as an interactive approach between literary language and the language of nature?

As Christopher Manes notes, in his article on Nature and Silence, "To regard nature as alive and articulate has consequences in the realm of social practices" (1996:15). Manes believes that understanding of nature is often influenced by power forces, both historical and modern. In this respect, what William Rueckert terms "literary ecology" questions whether existence is ignored, suppressed or forced aside, in Manes's words, "into a hazy backdrop against which the rational human subject struts upon"(1996:16). This viewpoint reveals that literary ecology is a translation into the natural world of human ideas regarding personal duty. Eco-literary dialogue, however, may explore how literary texts express nature's silence, and to what consequences (Oppermann, 1999: 3-4).

Therefore, ecocriticism should examine what we might term a discursively distorted nonhuman environment in writing, and analyze whether it gets ignored, suppressed, or integrated into the human language. (Oppermann, 1999: 3-4) Ecocriticism, in this framework, offers an "analysis of the cultural constructions of nature, which also includes an analysis of language, desire, knowledge, and power" (Legler, 1997: 227).

What role does the physical-geographical setting play in the structure of the novel or a poem?

Geography has emerged in recent years as a dynamic field that spans the natural and social sciences. A leading college text is James H. Brown and Arthur C. Gibson, Biogeography (St. Louis: C. V. Mosby, 1983), which explains how geological and ecological processes create the geographical distribution of plants and animals, William Norton examines how sociology, geography, and ecology study landscape by defining the physical and ideological structures that create patterns of human land-use and settlement (Norton, 1989). The geographical psychology of landscape is the main concern (Porteous, 1990), which attacks the banality of modern urban life as a surface "landscape-only" view of the world, devoid of the sensuous freedom and playful exploration of childhood. 
How do our metaphors of the land influence the way we treat it? That is, what is the link between pedagogic or creative practice and actual political, sociocultural and ethical behaviour towards the land and other non-human life forms?

After 1960, ecology advanced from description to advocacy, as its stories presented ethical choices affecting land and people. Much like the Planet (Kepes, Hall) received telescopes and satellite images, so did ecological research form a modern ethos in landscape literature. Yet in fact, texts do reflect how a civilization regards its natural heritage. We know nature through images and words, a process that makes the question of truth in science or literature inescapable, and whether we find validity through data or metaphor, the two modes of analysis are parallel. Ecocriticism observes in nature and culture the ubiquity of signs, indicators of value that shape form and meaning. Ecology leads us to recognize that life speaks, communing through encoded streams of information that have direction and purpose, learn to translate the messages with fidelity (Howarth, 1996: 75-77).

\section{The Concerns of Eco-Criticism}

Ecocritics assume that the real environment is connected with human nature. Ecocriticism presumes that all aspects of life are intertwined. Ecocriticism expands the concept of "the world" to encompass the entire ecosphere.

There is a clear relation between nature and society, in which textual care, depiction and "thematisation" of land and environment determines land behavior.

\section{Eco-poetry, its features, and Green Plants Ecological Poetry and its Main Features}

During the 1990s, ecocriticism exploded onto the critical scene, producing fascinating and important works that enabled us to see significant literary arena. Gilcrest separates "ecopoetry" from modern poetry of nature as well as conventional romantic poetry, and he characterizes it as defined by a criticism of atomistic and mechanistic conceptual schema; an identification of an environmental crisis based on those schemas; an appeal to revolutionary transformations based on ecological science; and the origin of an ecocentric ethic of interconnectedness, reciprocity, and in some instances, radical egalitarianism (Bryson, 2005: 2).

As J. Scott Bryson (2002: 5-6) points out, there are two main features of ecopoetry. The first is an "ecocentric perspective" where the focus of attention is not only humanity but also the natural world. In other words, we are the universe's nucleus, our interactions in the community, governed by what individuals have achieved and are doing. The second feature is that a poem should establish a new consciousness of defending the natural environment. It is not humanity but nature, which is superior and should be defended and respected. Interrelatedness is another feature which is basically summarized as "everything is connected to everything else" (Commoner, 1971).

Ian McHarg one of the deepest thinkers tried to design a new model of reality based on ecology, says that "perhaps the greatest conceptual contribution of the ecological view is the perception of the world and evolution as a creative process." He defines creation as the elevation of matter from 
the lower to the higher order. In fact, he states, this occurs when any energy from the sun is lost on its journey to entropy. He calls this cycle of entanglement. It allows energy to be saved from spontaneous dispersal and placed to creative ends (Ho Warth, 1996: 111).

Green plants are perhaps the most imaginative species on earth, for example. These are the poets of nature. The ways in which this concept can be applied to the human community are not ending. Poems are green plants among us; if poets are suns, poems are green plants among us because they simply arrest energy on their journey to entropy, not only increasing matter from lower to higher order, but also helping to build a structure that is self-perpetuating and evolving. That is, they help to create creativity and community, and when their energy is released and flows out into others, raise matter again from the lower to the higher order (to use one of the most common descriptions of what culture is).

One of the reasons why teaching and the classroom are so important (for literature, anyway) is because they intensify and continue this process by providing the environment in which the stored energy of poetry can be released to carry on its work of creation and community. The greatest teachers (the classroom's best ecologists) are those who are able to generate and release the greatest amount of collective creative energy; they are the ones who believe that the classroom is a community, a real interactive field. While few of us - maybe none of us - comprehend exactly how this concept can be used to the ends of biosphere safety, its discovery will be one of the key problems an eco- friend might have ecological poetics would have to address.

\section{Gary Synder's Ecological Consciousness Poems}

Snyder believes that nature is made up of microscopic organisms, animals, plants, and human societies. He calls for nature's safety from civilization's destruction and encourages humans to be in contact with their "wild" selves and return to a sense of unity with nature. While Snyder belongs to the deep ecology school, he often correlates his concerns with social ecology (Al Jumaili, 2013: 25).

Social ecology is specifically associated with the discussion regarding modes of dominance in the human environment, and whether this relates to nature domination. This stresses that the response to human impact of non-human environment is a collective one while deep ecology is more concerned with transforming individual consciousness because it derives from views of theology and ideology. Snyder deals on both, highlighting the need to shift mindset and supporting societal reforms to harmonize the interaction between human beings and non-human entities (Al Jumaili, 2013: 25).

Gary Snyder has a broad, varied body of research that covers a vast range of topics, but one that he often returns to is one of human interaction with nature. Snyder describes nature as divine, and that goes hand in hand with the biocentered nature of his belief in Buddhism. For Buddhists, seeing the Buddha nature surrounding them brings divine meaning to the natural environment. The sense is evident in poems by Snyder. (Earle, 2003) 


\title{
8.1 The Implication of ecopoetry in Snyder's poems
}

Riprap poetry "Water" the poems reflect the time spent in Yosemite by Snyder as a trail crew planting Riprap, placing the rock pavement in trails to protect them from eroding. The poem says:

\author{
"Pressure of sun on the rockslide \\ Whirled me in a dizzy hop-and-step descent, Pool of pebbles buzzed in a Juniper shadow, Tiny \\ tongue of a this-year rattlesnake flicked, \\ I leaped, laughing for little boulder-color coil---- \\ Pounded by heat raced down the slabs to the creek Deep tumbling under arching walls and stuck \\ Whole head and shoulders in the water: \\ Stretched full on cobble ears roaring \\ Eyes open aching from the cold and faced a trout." (Snyder, 2004, p.12)
}

Throughout the sense of the natural universe, this poem reveals Snyder, although the fact that Snyder does not discuss his existence until the fifth line of the poem indicates that he is just a minor part of the world - not a powerful entity. Snyder doesn't say anywhere in the poem that he has a more important place than any other part of the ecosystem, rather it suggests that he is an equal. It is seen in the final line of the poem, where he ends up meeting up with a shark.

Although this might be a summary of a concrete occurrence, Snyder's method of describing it; expresses broader ecological and theological ramifications. The universe that Snyder depicts in the poem is one in which everyone has a position and is essential, and implies that all other modes of existence are equivalent to human life.

Snyder 's poem "For All" sets the American Pledge of Allegiance take on a new spin. Instead of promising loyalty to a flag, Snyder promises loyalty to the land, saying,

"I pledge allegiance to the soil of Turtle Island, and to the beings who thereon dwell one ecosystem

in diversity under the sun

With joyful interpenetration for all." (Snyder, 2000, p.504)

This is a groundbreaking move to establish a modern oath of allegiance. Snyder moves the emphasis off national culture and places it on nature instead. Although the initial Pledge of Allegiance references Christ, Snyder substitutes Him with the light. By so doing, he transfers the emphasis from an abstract entity to a living object. And like Christ is viewed as an essential lifegiving force, so will the sun be seen as well - without the energy that the sun offers, the existence of plants, animals and humans will be unlikely. Through swapping Christ with the earth, Snyder claims that the world is within itself a total and holy being.

It is also worth noting that the new pledge of loyalty given by Snyder does not make any specific mention of humans. It indirectly applies to humans in the paragraph, "and to the entities that live thereon," but the poem never sets humans above the other types of existence on Turtle 
Island. Again, this reflects Snyder's conviction that human beings are only a part of the universe and not really the most significant.

Snyder defamiliarizes itself by rendering scientific assumptions on merely natural phenomena, in reaction to the socially and morally abstract terms in which "it" is still considered in our postmodern, late imperialist, globalizing "age" which so clear in Ripples on the Surface:

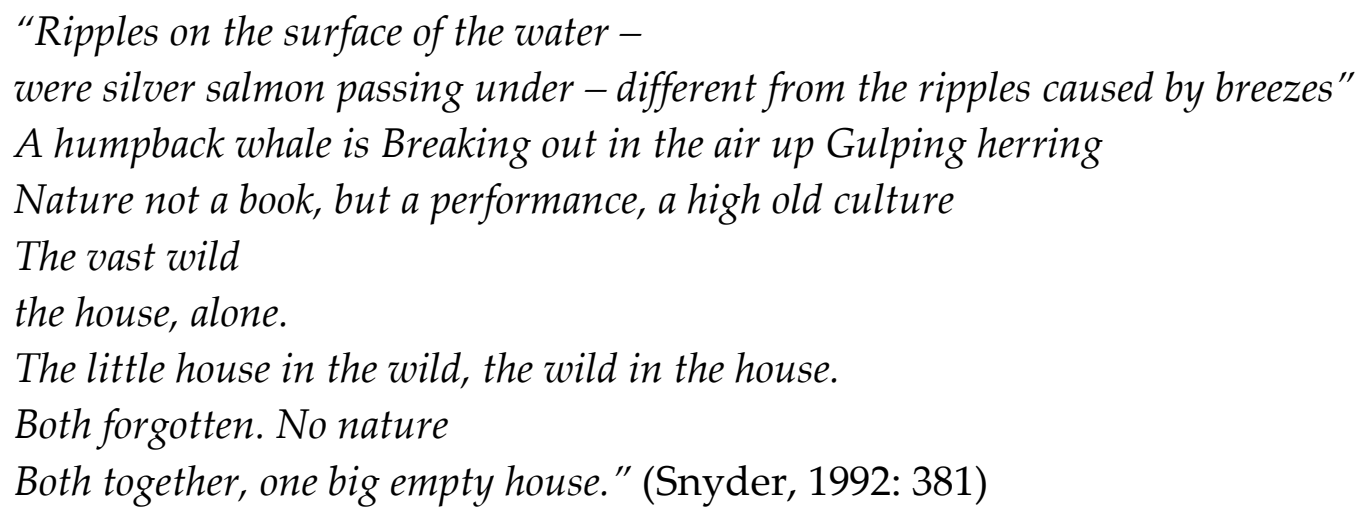

The house reflects the human environment, but Snyder places it alone in "the great wild," implying that modern culture is only a tiny part of the planet. Snyder also draws attention to this idea by reiterating it in the next stanza: "the little house in the wild." In the last stanza, Snyder's perception of the human relationship with the natural environment is quite evident, calling both the small house and nature "one big, empty house."

All-human homes and environment-is a broad world that we both inhabit and work in. The usage of the term "wild" by Snyder gives the term a specific sense, since while wildness is always synonymous with bad, "the wild [is] in the house." They would accept it instead.

The poem that lends its title to the first section of Turtle Island, "Manzanita," appears to be a song about plant life. The poem shows the concept of "ethnobotany" by Snyder, and the use of vegetative life in human culture. The poem honors the actual immediate environment:

"Manzanita the tips in fruit, Clusters of hard green berries The longer you look

The bigger they seem,

"little apples"." (Snyder, 1974:1)

The poem indicates the important element in maintaining a balanced existence is natural diversity. This is peace and prosperity can only be accomplished by maintaining the natural world's richness. "Charms," this section's last line, on the other side, refers to animal existence. When "Manzanita" describes a realm of plants "Charms" introduces the realm of animals.

As Hunt finds out, "Rocks, trees, sheep, rabbits, coyotes, eagles, lions, deers, and ravens all talk to Snyder, through him and to him" (Hunt, 2004:1). Taken together, these two poems not only represent Snyder's modern form of writing, but also illustrate "Why songs of wisdom and nature can serve to rehabilitate the ground" (Molesworth, 1983:101). In reality, each poem "speaks to a consciousness made up of a complete harmonization between man and nature, and between man and man". 
"Walking the New York Bedrock" from Mountains and Rivers Without End (1996), regarded by others to be the most significant work of Snyder, examines the forest in the environment of the region. The poem is about the life of plants and animals inside the region. Snyder is not showing contempt towards the built climate. As Christopher Benefy points out, "Snyder imagines the environment of wild nature beyond the society system" (Snyder, 1979: 42):

\author{
"Squalls \\ From the steps leading down to the subway. Blue-chested runner, a female, on car streets, Red \\ lights block traffic but she like the \\ Beam of a streetlight in the whine of Skilsaw, She runs right through. \\ A cross street leads toward a river North goes to the woods \\ South takes you fishing \\ Peregrines nest at the thirty-fifth floor." (Snyder, 1996: 100-101)
}

When observing the city in a dreamlike view, the speaker begins to realize that by heading to the surrounding forests and rivers, he may leave this city, but he doesn't have to. In the region as well as throughout the country one can get lighting. Therefore, city and nation are not at odds. Where you are, you have to inhabit the place, profoundly know it, and flow with it. The wild peregrine hawk, like the ginkgo trees in the subway, is at "safe" on a ledge "in the thirty-seventh story" (Hunt 2004:187). Snyder's understanding of society varies from the opinions of the Beat authors.

While the Beat writers like Jack Kerouac and Allen Ginsberg reject the urban way of life and oppose civilization of all kinds, Snyder does not. Through celebrating nature and wild life, Snyder believes that without going to the mountains, one can explore the wild within the city and gain enlightenment. Therefore, living in the woods or in the city doesn't make much sense for Snyder because he can be educated in both. Even within the city, Snyder can discover the wild and the wilderness has acquired additional meaning from what Thoreau and Whitman knew. In the second half of the 20th century, Snyder elevates the wild and was his poet, yet adds a new urban dimension to it.

Snyder once said to New York Quarterly, "It's just putting me in a different position in the network, which doesn't suggest I'm any less involved in the network as a whole, it's just that's where I'm focused" (Snyder 1980: 37). The concept of the food chain believed by Snyder can be detected in the difference between the "street-bottom feeders" and those occupying "sunnier niches" and the peregrine hawk feeding off the pigeon to survive. "Walking the New York Bedrock" shows the city's wild dispersed:

\begin{abstract}
"The lessons we learn from the wild become the etiquette of freedom. We can enjoy our humanity with its flashy brains and sexual buzz, its social cravings and stubborn tantrums, and take ourselves as on more and no less than another being in the Big Watershed... The wild requires that we learn the terrains, and nod to all the plants and animals and birds, ford to the streams and cross the ridges. And tell a story when we get back home." (Snyder, 1990: 24)
\end{abstract}




\section{Conclusion}

From the first sight, eco-writers walked in a very different side than the other modernist literary movements, by creating a new perspective of loyalty to the nature. Since poetry is the most influenced and significant part in any literary movement, ecological consciousness poetry played the major role in ecocricism, by showing and highlighting that the every single entity is important, and significant as much as the others, weather it was a human being, animal, or even plants. In other words, everything is related to everything.

Gary Snyder who is in my opinion the pioneer of the ecological consciousness poetry, established a strong interest in nature as a youth experiencing a traditional "other" at the Museum of Art in Seattle. The seed which this early encounter has planted in him, this early knowledge of a strong connection with Chinese landscape paintings and the Chinese view of nature will help him far later, in his magnum opus writings. After living most of his life with Chinese and Japanese societies, Snyder influenced by the Buddha's culture and perspectives, especially how do they treat and read nature. He translated that passion and influence of these cultures in his literary writings, which made his poetry, prose, and essays, revolutionary movement toward the western literature.

Snyder claims that environment consists of microscopic species, plants, livestock and human cultures. He advocates for the protection of nature from the devastation of humanity, Snyder Believes that nature has got divinity. We should return to our motherland of divinity devoid of impurity of modernism. Though Snyder belongs to the school of deep ecology, he also compares his issues with social ecology.

Finally, Gary Snyder definitely succeeds in conveying and creating a new revolution in literature in general, by his great collection of writings, weather it was in poetry or in prose.

\section{Conflict of Interest Statement}

This manuscript has not been submitted to, nor is under review at, another journal or other publishing venue. The author has no affiliation with any organization with a direct or indirect financial interest in the subject matter discussed in the manuscript.

\section{About the Authors}

Zaid Najah Merzah is an Assistant Lecturer of English Literature at Imam Ja'afar Al-Sadiq University, Faculty of Arts. Born in Najaf, Iraq, Holds, B.A. in English Language and Literature 2010, University of Kufa, College of Arts, Iraq, and a M.A. in English Language and Literature 2015. He has published several research articles and a book.

Alaa Ahmed Idrees is a teacher of English at the University of Kufa, Faculty of Languages. Born in Najaf, Iraq, Holds, B.A. in English Language and Literature 2020, University of Kufa, Faculty of Languages, Iraq. 


\section{Bibliography}

Al Jumaili, F. (2013). An Ecocritical Reading of Gary Snyder's select poetry. Malaysia: University of Malaya.

Al Jumaili, F. (2014). Gary Snyder's Ecological Vision: A study of Selective poetic. Malaysia: University of Malaya. Bennet, W. (1996). Human Ecology as Human Behaviour, New Brunswick. London: Transaction Publishers

Bryson, J. S. (2002). Introduction. In: J. Scott Bryson. ed. 2002. Ecopoetry. A Critical Introduction. Salt Lake City: University of Utah Press.1-13.

Bryson, J. S. (2005). The West Side of Any Mountain: Place, Space, and Ecopoetry. University of Iowa Press.

Commoner, B. (1971). The Closing Circle: Nature, Man, and Technology. New York: Knopf ISBN 978-0-394-42350-0.

Camphell, J. (2005). High peak haikus. London: The Guardian. As cited from: https://www.theguardian.com/books/2005/jul/16/featuresrevi ews.guardianreview19

Glotfelty, C. \& Fromm, H. (eds) (1996) The Ecocriticism Reader: Landmarks in Literary Ecology. Athens, Georgia \& London: The University of Georgia Press.

Gogoi, G. (2014). An Ecocritical Approach to Chinua Achebe's Things Fall Apart and Arrow of God. IOSR Journal of Humanities and Social Science (IOSR-JHSS)

Ho Warth, W. (1996). Some principles of ecocriticism. The ecocriticism reader: Landmarks in literary ecology. Georgia: University of Georgia Press

Hunt, A. (2004). Genesis, Structure, and Meaning in Gary Snyder's Mountains and Rivers Without End. Reno: University of Nevada Press

Legler, G. T. (1997). Ecofeminist Literary Criticism. Philpapers.org

Martz, Louis L. (ed) (1986). H. D. Collected Poems: 1912-1944. New York: A New Directions Book.

Molesworth, C. (1983). Gary Snyder's Vision; Poetry and the Real Work. Missouri: University of Missouri Press.

Norton, J., \& Snyder, G. (1987). The Importance of Nothing: Absence and Its Origins in the Poetry of Gary Snyder. Contemporary Literature

Norton, W. (1989). Exploration in the Understanding of landscape. New York: Greenwood Press.

Oppermann, S. (1999). Ecocriticism: Natural World in The Literary Viewfinder. Ankara-Turkey: Hacettepe University, Journal of Faculty of Letters.

Porteous, J. (1990). Landscape of the Mind: Worlds of Sense and Metaphor. Toronto: Toronto University Press.

Rueckert, W. (1996). Literature and Ecology: An Experiment in Ecocriticism in Glotfelty and Fromm. The Environment \& Society Portal

Snyder, G. (1974). Turtle Island. New York: New Directions Publishing.

Snyder, G. (1979). He Who Hunted Birds in His Father's Village: The Dimensions of a Haida Myth. New York: Grey Fox Press

Snyder, G. (1980). The Real work: Interviews \& Talks. New York: New Direction.

Snyder, G. (1990). The Practice of the Wild. San Francisco: North Point Press. 
Snyder, G. (1992). No Nature: New and Selected Poems. New York: Pantheon Books

Snyder, G. (1996). Mountains and Rivers without End. New York: Counterpoint.

Snyder, G. (2000). The Gary Snyder Reader. New York: Counterpoint.

Snyder, G. (2004). Riprap and Cold Mountains Poems. Washington: Shoemaker \& Hoard.

Creative Commons licensing terms

Author(s) will retain the copyright of their published articles agreeing that a Creative Commons Attribution 4.0 International License (CC BY 4.0 ) terms will be applied to their work. Under the terms of this license, no permission is required from the author(s) or publisher for members of the community to copy, distribute, transmit or adapt the article content, providing a proper, prominent and unambiguous attribution to the authors in a manner that makes clear that the materials are being reused under permission of a Creative Commons License. Views, opinions and conclusions expressed in this research article are views, opinions and conclusions of the author(s). and European Journal of Literature, Language and Linguistics Studies shall not be responsible or answerable for any loss, damage or liability caused in relation to/arising out of conflicts of interest, copyright violations and inappropriate or inaccurate use of any kind content related or integrated into the research work. All the published works are meeting the Open Access Publishing requirements and can be freely accessed, shared, modified, distributed and used in educational, commercial and non-commercial purposes under a Creative Commons Attribution 4.0 International License (CC BY 4.0). 